Provided for non-commercial research and education use. Not for reproduction, distribution or commercial use.

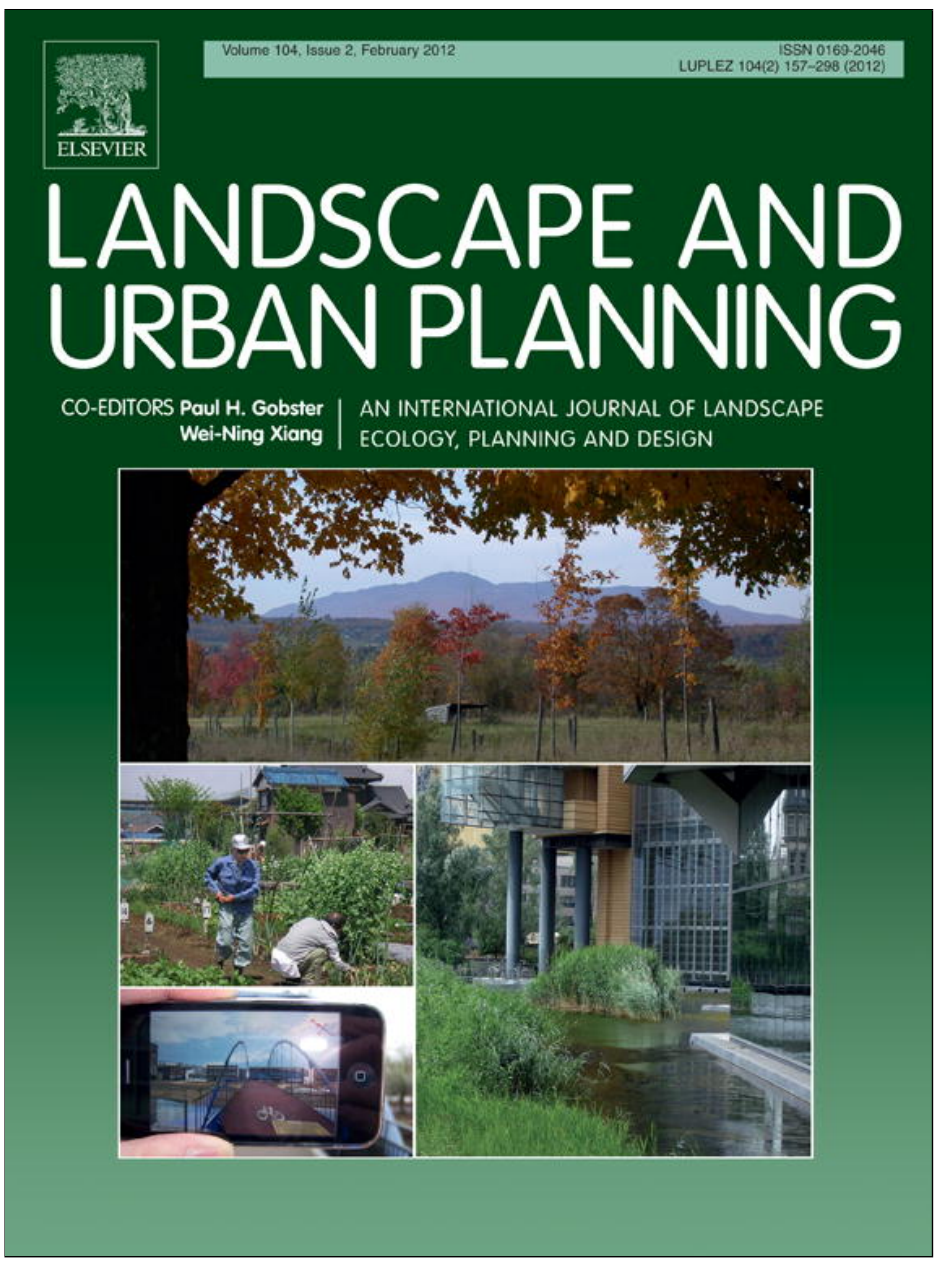

This article appeared in a journal published by Elsevier. The attached copy is furnished to the author for internal non-commercial research and education use, including for instruction at the authors institution and sharing with colleagues.

Other uses, including reproduction and distribution, or selling or licensing copies, or posting to personal, institutional or third party websites are prohibited.

In most cases authors are permitted to post their version of the article (e.g. in Word or Tex form) to their personal website or institutional repository. Authors requiring further information regarding Elsevier's archiving and manuscript policies are encouraged to visit:

http://www.elsevier.com/copyright 


\title{
Flood risk assessment and mapping in peri-urban Mediterranean environments using hydrogeomorphology. Application to ephemeral streams in the Valencia region (eastern Spain)
}

\author{
A.M. Camarasa-Belmonte*, J. Soriano-García \\ Department of Geography, University of Valencia, Avda. Blasco Ibáñez, 28, 46010 Valencia, Spain
}

\section{A R T I C L E I N F O}

\section{Article history:}

Received 2 February 2011

Received in revised form 4 October 2011

Accepted 7 October 2011

Available online 5 November 2011

\section{Keywords:}

Hazard

Exposure

Flood-risk map

Land-use

Mediterranean

Ephemeral stream

\begin{abstract}
A B S T R A C T
This paper proposes a methodology for mapping flood risk in ephemeral streams, based on assessing flood hazards and global exposure. The method has been applied to the peri-urban area of Valencia, extended over the floodplains of the Barranco del Carraixet and Rambla de Poyo catchments. Hazard was assessed using hydrogeomorphological methods. Global exposure was estimated as a combination between the economic value of land use and human exposure, following a previous study carried out by Camarasa, A.M., López, M.J. and Soriano, J., 2011. Mapping temporally variable exposure to flooding in small Mediterranean basins using land-use indicators, Applied Geography 31 (19), 136-145. Synthesis mapping was elaborated to spatially rank flood risks, in terms of their hazard and exposure components. The method is simple, effective and easily comparable. The results reveal diverse risk configurations for each floodplain, even though both are in the vicinity of Valencia city (metropolitan area). This flood risk mapping method is very useful for land use planning because it enables swift diagnosis of the nature of risks and can supports decision making by risk managers and urban planners.
\end{abstract}

(C) 2011 Elsevier B.V. All rights reserved.

\section{Flood risk components in Mediterranean ephemeral streams}

Flooding is the greatest natural risk in Mediterranean environments. In Spain over the last 20 years, floods have accounted for over $81 \%$ of the resources required to mitigate damages as a result of extraordinary risks (Insurance Compensation Consortium, 2008). Within Spain, the Mediterranean coast accounts for the majority of floods mainly as a result of the numerous torrential ephemeral stream systems.

Addressing the risks associated with these river systems implies studying both the physical events that cause the problem and the human occupation of the affected areas (Adger, 2006; Hooke \& Mant, 2000; Hooke, 2006; White, 1974; Wisner, Blaikie, Cannon, \& Davis, 2004). In other words, flood risk assessment involves evaluating its three main components: the hazard, or probability that a flood reaches a certain threshold; vulnerability or "the potential adverse consequences, especially for human health, the environment, cultural heritage and economic activity" (European Floods Directive, art. 2.2); and exposure defined as "an inventory of those people or artefacts that are exposed to a hazard" (UNDP,

\footnotetext{
* Corresponding author. Tel.: +34 363864237 .

E-mail addresses: ana.camarasa@uv.es (A.M. Camarasa-Belmonte), jusogar@alumni.uv.es (J. Soriano-García).
}

2004). The case of Mediterranean ephemeral streams has certain peculiarities compared to other river systems, both from a physical and human viewpoint, which must be taken into account so as to correctly analyze the hazard, vulnerability and exposure components.

From a physical point of view (and thus hazard-related) these basins are small (several hundred $\mathrm{km}^{2}$ ), but are highly torrential and generate flash-floods (Camarasa, 2006; Dick, Anderson, \& Sampson, 1997). Geomorphologically, the catchments have sharp slopes, broad valleys and braided channels (Camarasa, 1995; Tooth, 2007; Yair \& Raz-Yassif, 2004). Hydrologically, these systems depend on rainfall (because of the absence of base flow). They are waterless most of the year, but during flood events they become particularly dynamic. High magnitude and low frequency events dominate water flow in these systems (Camarasa \& Segura, 2001; Camarasa \& Tilford, 2002).

Mediterranean storms which generate floods in ephemeral streams are particularly intense (Bull, Kirkby, Shannon, \& Hooke, 2000; Lana, Martínez, Serra, \& Burgueño, 2004). A single event can double or triple the annual average and can frequently exceed $100 \mathrm{~mm} / \mathrm{h}$ and reach maximums in excess of $355 \mathrm{~mm} / \mathrm{h}$ in $5 \mathrm{~min}$ (Camarasa, Soriano, \& López-García, 2010). Alongside the intensity of the rainfall, other factors (Bull et al., 2000; Greenbaum, Margalit, Shick, Sharon, \& Baker, 1998) such as the coalescence of tributaries, the storm track and steep slopes are critical to the generation of flash-floods. The hydrographs are steep, with pointed peaks and 
short lag times (Braken, Cox, \& Shannon, 2008; Camarasa \& Segura, 2001; Dick et al., 1997; Renard \& Keppel, 1996).

In addition to the water discharge hydrograph, it is essential to point out the importance of the sediment the system is capable of carrying (Megnounif, Terfous, Ghenaim, \& Poulet, 2007). The torrential behavior of these basins in high-energy events implies large-scale geomorphic activity resulting in the generation, transport and deposition of large amounts of sediment, among other elements (Conesa-Garcia, 1995; Lasanta, García-Ruiz, PérezRontomé, \& Sancho-Marcén, 2000; Yair \& Kossovsky, 2002). A direct consequence of this energy is the changes that can occur in the morphology of the channels and the floodable areas from one event to the next.

From the hazard viewpoint, this fact affects the difficulty in obtaining flow data in ephemeral streams, given the technical problems involved in gauging dry riverbeds. In addition, the fact that the shape of the floodplain may change can have an influence on the type of flood and on the spatial pattern of the overland flows (Jin \& Ward, 2005; Lewin \& Manton, 1975). In other words, ephemeral streams, like other semi-arid river systems, are variable floodable areas which change over time because they are dominated by highenergy events. As indicated by Graf (1988), processes control forms in high magnitude events (while forms control processes in low magnitude events).

Finally, despite the fact that the hydrogeomorphological operation of these systems is well known (Bull et al., 2000; Hooke and Mant, 2000; Merrit \& Wohl, 2003; Ortega \& Garzón, 2009) the literature on modeling system dynamics is scarce (Servat, Najem, Leduc, \& Shakeel, 2003). This shortage stems from a lack of quality, detailed hydrological data with which to analyze the processes and fit the models. Furthermore, both scientific literature and technical tests using simulation models have focused on monitoring perennial rivers in humid environments, which are more economically productive and whose behavior is more "normal" in standard hydrological terms. Some examples of ephemeral streams' lack of "normality" include: (a) the absence of base flow; (b) the reduced influence of the basin in rainfall-runoff conversion processes during high-energy events (Camarasa \& Tilford, 2002); (c) the large volume of transmission losses during the flood which can transfer the majority of the water to throughflow paths; and (d) the effect of extreme rain intensity at the beginning of the storm on the rainfall-runoff conversion outcomes, inhibiting the infiltration processes in favour of the formation of overland flow, even though the soil is not yet saturated (Camarasa, 1995). In short, from the hazard viewpoint, in Mediterranean ephemeral streams, floods are especially fast, powerful, difficult to simulate using models and, therefore, very dangerous.

Secondly, from the viewpoint of human activity in the floodable areas (and thus related to vulnerability and exposure) there are three important factors: the intense human occupation of the floodplains, the inadequate perception of risk by the population and the short lag time to react to the hazard.

In ephemeral streams, floodable areas are linked to piedemonts, alluvial fans, graben and tectonic valleys, and to coastal plains. Although these areas are small, the majority of human activity is concentrated in them. Firstly, the fertility of the soil, the benign Mediterranean climate and the proximity to water courses make these areas particularly productive. These areas have been intensively farmed since ancient times and have always given high yields. In the 20th century a phase of land abandonment occurred. Although this phenomenon can have positive or negative effects (depending on the ability of land to recover its natural cover), the general assumption is that vegetation cover tends to increase and erosion rates decrease some years after abandonment (Hooke, 2006). In addition, the flat topography of floodplains has attracted roads and railways, industries, towns and villages.
In Spain, floodplains were heavily occupied during the economic development of the 60s and 70s despite the flood risks. In recent decades, huge areas of the territory have been turned into farming land ( $50 \%$ of the area is used for agriculture) while there has also been increasing development (according to the Spanish National Statistics Institute, the artificial surface area grew by around 30\% between 1991 and 2001). It should be noted, however, that the change in irrigation methods has decreased soil erosion as traditional surface irrigation techniques have been replaced by new drip irrigation systems. From 1987 to $2000,12 \%$ of the surface area of rivers and natural channels was lost (7508 hectares) as a result of channelization and other human interventions.

Alongside this growing human occupation of floodable areas, the risk perception of the population which is exposed to danger is low (Aven \& Kristensen, 2005; Brilly \& Polic, 2005; Dake, 1991). This stems from a "false sense of security" caused partly by the fact that the riverbeds remain dry for a large part of the year (collective memory is very short with respect to flood disasters when there is no water around), and partly as a consequence of the possible construction of structural protection measures. In some cases, low risk perception is not due to a "false sense of security" but to actual experience. For example, cases where the river changes its pattern of flooding, either because of natural river processes (changes in erosion-deposition processes, incision, bank breaks, activation of paleochannels, etc.) or of human interventions (engineering works). In both cases, hazard patterns change and previously dry areas may be exposed to floods. The final factor which increases vulnerability is the short lag time both the human population and the Civil Defense and Emergency Management Services have to react, as the basins' flood response to rain takes place in just a few hours (Camarasa et al., 2010; Romero, Ramis, \& Guijarro, 1999).

In short, from the vulnerability and exposure viewpoints, ephemeral streams are floodable areas with high human occupation which have traditionally been intensively farmed and which concentrate increasingly large numbers of economic and residential activities. As both risk perception and management are deficient, risk mapping may constitute a highly efficient alternative or complementary tool for flood risk management in spatial planning. To accurately map flood risks in this context, it is necessary to specify and adapt the concepts of hazard, vulnerability and exposure to the case of ephemeral streams and develop suitable methodologies to estimate them. While the physical dimensions of hazards are clear in theory, the human concepts of vulnerability and exposure are more difficult to define, estimate and map (due to their multiple social, economical, political and cultural dimensions). Bohle (2001) distinguishes between external vulnerability (comparable to exposure) and internal vulnerability (referred to as the social capacity to cope with and mitigate the negative effects of catastrophes). However, this conceptual approach may be a bit confusing, especially when, as in the present case, internal vulnerability is very similar throughout the whole area of study. Therefore, this paper focuses its analysis of human aspects on assessing and mapping exposure (both people and goods).

This paper discusses the development of flood risk cartography on the peri-urban environment of Valencia, extended over the floodplains of two typically Mediterranean ephemeral streams (the Barranco del Carraixet and the Rambla de Poyo), by estimating hazard and exposure. Hazard was assessed using hydrogeomorphological methods, given the difficulty of applying hydrological and hydraulic methods to ephemeral streams. In terms of exposure, it should be pointed out that both floodplains are located in the area of influence of the city of Valencia (metropolitan area) where intense processes of urban expansion have taken place in recent decades. As mentioned above, exposure was estimated using the results of a previous study on the same area by Camarasa, López-García, \& 
Soriano (2011), in which global exposure was assessed according to simple indicators based on land use (in relation to its economic value and concentration of human exposure).

Finally, types of floodable areas are presented according to the intensity and quality of their hazard and exposure components. This constitutes a highly useful synthesis map for regional management (as it points risk reduction strategies towards hazard or exposure).

\section{Case studies: the Carraixet and Poyo floodplains}

\subsection{Study area}

The Barranco del Carraixet $\left(311 \mathrm{~km}^{2}\right)$ and Rambla de Poyo $\left(462 \mathrm{~km}^{2}\right)$ basins were considered to be representative of ephemeral streams in the region (Fig. 1). These small catchments originate in the Iberian Range and reach the sea to the north and south of Valencia respectively. This means that the floodplains intersect with the city's metropolitan area. Both floodplains, together with the alluvial fan of the River Turia, form part of the coastal plain of the Gulf of Valencia (Camarasa, 1995).

Historically, human occupation has focused on the city of Valencia, around which intensive agriculture stands out as the main activity. The Carraixet and Poyo floodplains, which belong to the districts of l'Horta Nord and l'Horta Sud respectively, form part of this peri-urban belt and have gradually been occupied as a result of urbanization. This urban extension has increased the risk of floods. Although attempts have been made to control the problem by channeling the final stretch of rivers, the risk persists and has risen in recent years.

The whole of Spain has been subject to this trend, which began in the 70s as a consequence of major land use transformations carried out in the territory. New industrial and residential uses have occupied the peri-urban areas which were previously devoted to intensive agriculture. In the study area, the biggest changes occurred in the Poyo floodplain (l'Horta Sud), and were partly due to the diversion of the River Turia (towards the Poyo floodplain). The River Turia (located between Poyo and Carraixet streams) flowed through the city of Valencia until 1957, the year in which it caused a catastrophic flood in the city. As a result of this flooding, the final stretch of the river was channelized and diverted to the south of the city, while the section of river that ran through the city became a large garden. As a consequence, the Poyo floodplain suffered major changes in land use. Agricultural use was dismantled in favor of industrial use (furniture industry) and urban use (a conurbation with over twenty population centers emerged). Industrial growth in the plain of Carraixet was less important; thus this floodplain maintained its agricultural role and also currently serves as a bedroom community for the city of Valencia (Salom \& Albertos, 2006). Today both floodplains form a physically and functionally interrelated area, which is inextricably linked to Valencia.

\subsection{Methodology for mapping flood risk in Mediterranean ephemeral stream floodplains}

Until recent decades, mapping risk was reduced to mapping hazard. Although the theoretical approaches always took the anthropogenic factor into account - "without man there is no risk" (White, 1974) -, practical analysis focused on the physical event. This scenario began to change at the end of the last century. At the center of the UN Declaration of the International Decade for Natural Disaster Reduction (1990-1999), the scientific community established that risk is made up of hazard and vulnerability. As a result of this new framework, there has been a change in the methods and approaches for studying hazards. The need to include exposure as one of its key components was reinforced in the International Strategy for Disaster Reduction (Adger, 2006; Birkmann, 2007; Cutter \& Finch, 2007), which was also promoted by the UN, under which the Hyogo Action Framework 2005-2015 was created.

Despite these advances, in the case of flood risk mapping there is a considerable imbalance between the methods that address hazards and those which estimate exposure in that the former are much more developed than the latter. However, in the present context, we cannot assess risk without assessing exposure as it may be one of the keys to reducing risk (especially in the cases where structural anti-hazard measures have proved somewhat ineffective).

Given the particularities of Mediterranean ephemeral streams, the methodology used to estimate and map risk should consider the endemic lack of hydrological data, the torrential nature and energy of these systems, and the intense human occupation of floodable areas as key premises. Thus, a simple method (which does not rely on hydrological data) that can be easily transferred to similar basins, and is flexible (able to reflect changes in both hazards and exposure without incurring excessive costs) should be considered.

The flood risk methodology that was followed in this paper to try to comply with these premises in the pilot basins is described below. Fig. 2 shows the mapping model developed using GIS, although a detailed explanation of each phase is given in the corresponding sub-sections.

At this point, we should point out that the whole study is based on and refers to the year 2000, as the last high-magnitude floods registered in the Carraixet and Poyo ephemeral streams took place in October of that year. They generated interesting additional information such as sedimentary records, news releases and technical reports which allowed the phenomenon to be analyzed and the study methods to be checked and fine-tuned.

\subsubsection{Hazard assessment and mapping}

Multiple approaches can be used to map flood hazard. Generally speaking, three main methodologies can be established: historical and paleohydrological methods (Baker, Kochel, \& Patton, 1988; Benito et al., 2004), hydrogeomorphological methods, and hydrological-hydraulic methods (Lastra, Fernández, Díez-Herrero, \& Marquínez, 2008). These could be added to with the recent appearance of dendrogeomorphological methods (Díez-Herrero et al., 2008).

These broad-based groups do not rule out others; instead they should be used together to complement each other. Unfortunately, this is difficult in the case of ephemeral streams. On one hand, paleohydrological methods are not suitable for small dynamic basins such as ephemeral streams, while hydrological-hydraulic methods require large amounts of hydrological data which are not available in the majority of these systems. In fact, several authors have demonstrated the inadequacy of these methods in predicting extreme floods in Mediterranean basins (Ballais, Garry, \& Masson, 2005; Chave, 2002; Pilgrim, Chapman, \& Doran, 1988; Wheater, Sorooshian, \& Sharma, 2006).

The hydrogeomorphological method, however, is gaining in importance in these areas. It is based on the distribution and type of landforms and on the sediment generated during the floods to define the floodable areas and the processes which have occurred (Díez-Herrero et al., 2008). Although it is not a quantitative approach, it provides a reliable representation of the processes, it is economical, and in $80 \%$ of the cases enables decision-making (Marco, 2006). Applications in Mediterranean areas in the south of France (Ballais et al., 2005; Chave, 2002), Italy (Guzzetti \& Tonelli, 2004; Guzzetti, Stark, \& Salvati, 2005), and northwestern Spain (Lastra et al., 2008) have shown the effectiveness of the method in torrential basins with changing morphology and large-scale erosion potential in which hydrological information is scarce or non-existent. 


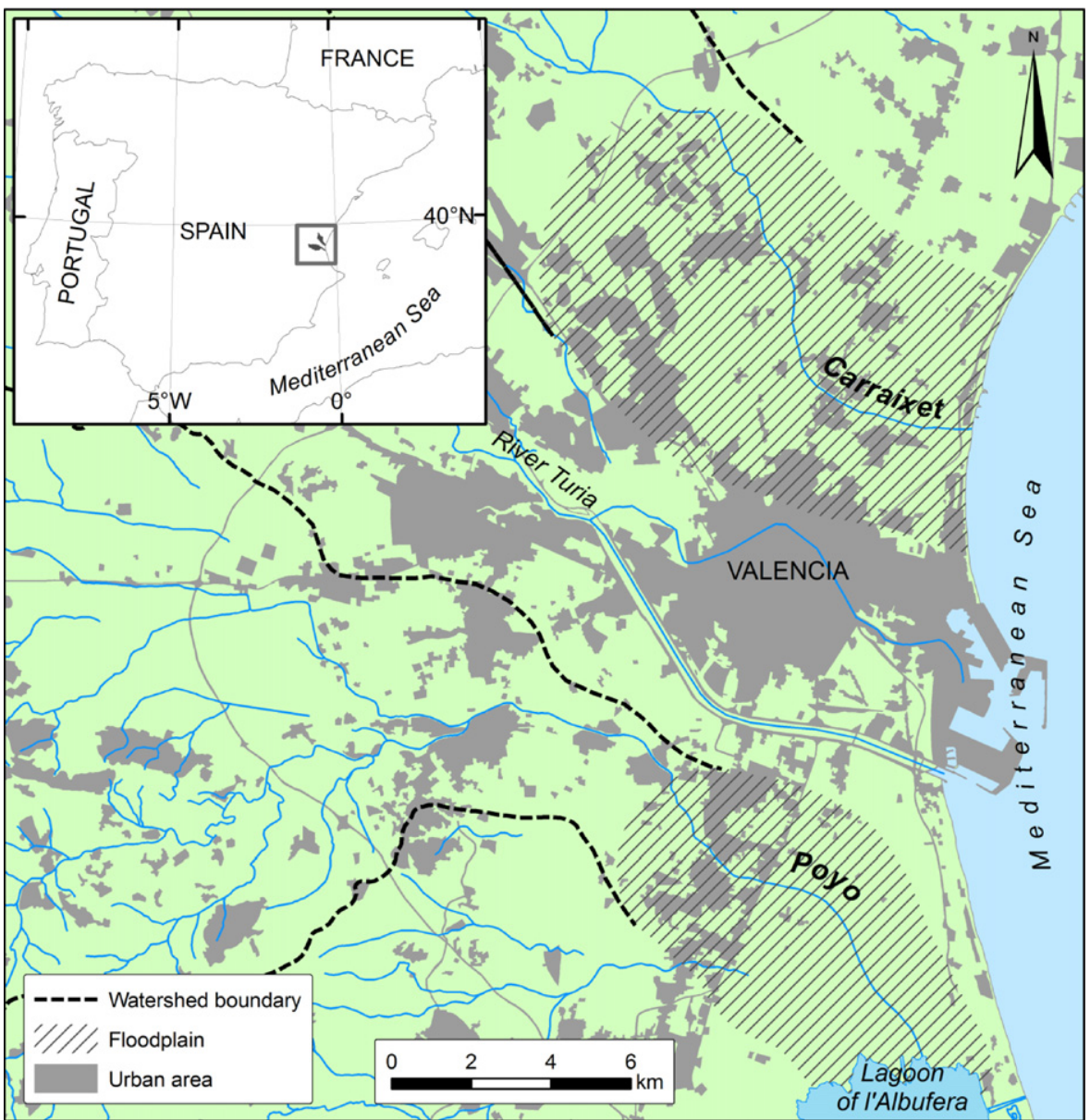

Fig. 1. Study area.

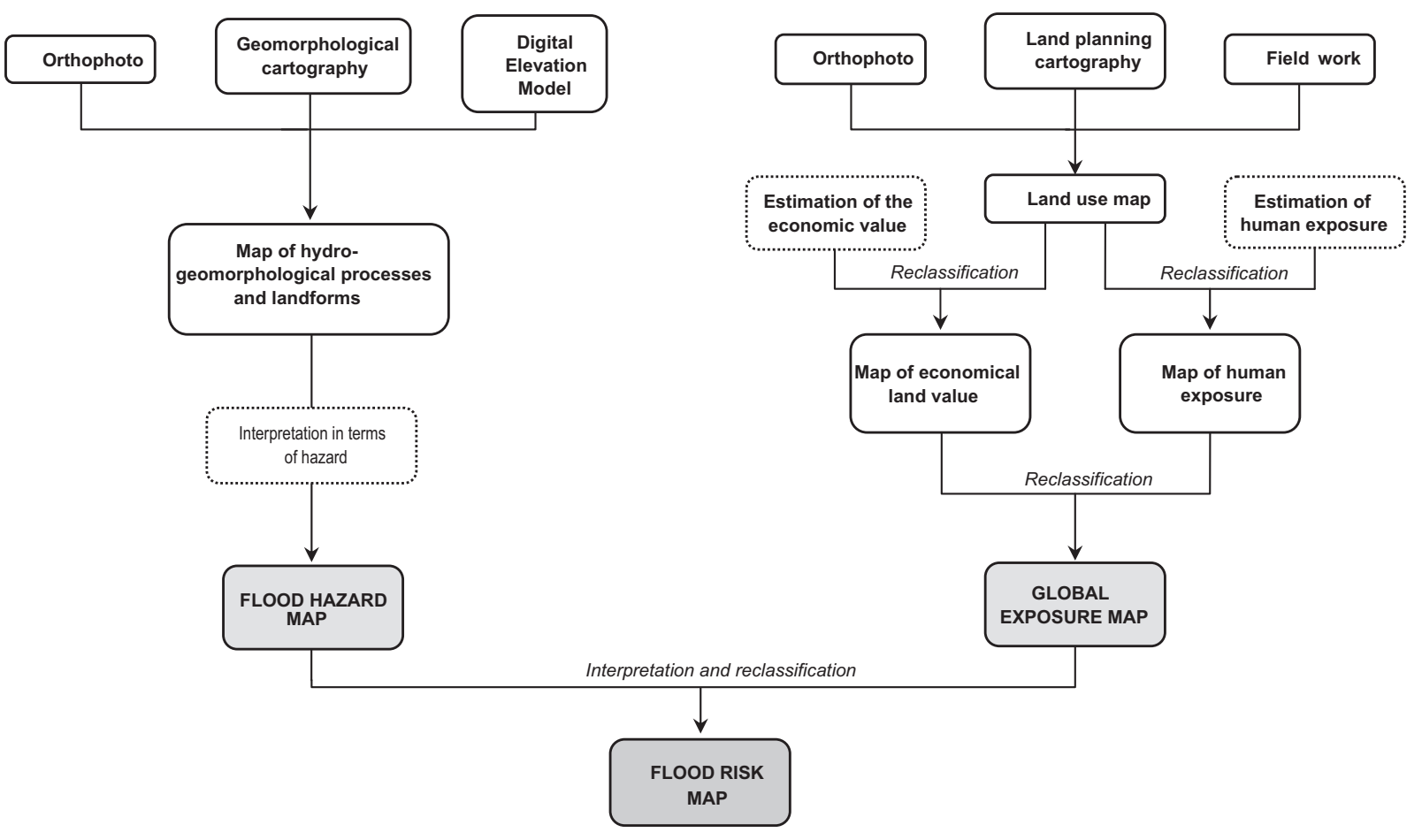

Fig. 2. Cartographic model. 
In this paper, hazard mapping is based on the interpretation and analysis of the floodplain's geomorphology, in terms of hazards. It centers on previous geomorphological studies carried out by Camarasa (1995) and Ruíz and Carmona (2004) on the Carraixet and Poyo floodplains. Likewise, it includes part of the detailed geomorphological mapping of the floodable areas, compiled by the aforementioned authors in the framework of the "Flood risk in Mediterranean ephemeral streams. Identification of hydrological and geomorphological thresholds" (REN2003-07171) research project.

A synthesis hydrogeomorphological map was drawn up based on these investigations, with the support of a Digital Elevation Model and an orthophoto from the year 2000. The DEM was built from a contour map at a scale of 1:5000 provided by the Cartographic Institute of Valencia (Regional Government), with a $1 \mathrm{~m}$ pixel resolution (reference system: Hayford ellipsoid, European Data 1950, UTM Zone 30 N). Orthophotos also have been provided by the Valencian Cartographic Institute showing a spatial resolution of $0.5 \mathrm{~m}$. Eighteen orthophotos were used to study the Carraixet floodplain and twenty-two for the Poyo floodplain.

Although the scale of some maps is quite detailed, the accuracy of data varies depending on the data source used. Therefore, we decided to work to a basic level of hazard diagnosis by identifying geoforms which, according to Ortega and Garzón (2009), could be classified as macroforms (decametric size) and mesoforms (metric size). A more detailed analysis (microforms) would have involved more intensive field-work and is not included in this paper. Thus thirteen different forms associated with flood processes were identified. These forms were qualitatively interpreted and assessed for hazards by hydrogeomorphological experts and through a bibliographic review (Table 1). They were divided into eight ordinal flood hazard levels, ranging from 1 which represented the greatest hazard - channels and critical points - through to 8 which referred to areas which were practically safe, i.e. mountains and longshore bars. Medium hazard levels were assigned according to an area's tendency to become waterlogged (for example, wetland) or to transport water (streambeds and paleochannels). Table 1 lists the hydrogeomorphological elements, gives a brief description of each one and shows the assigned hazard level.

\subsubsection{Exposure estimates and mapping}

Methodological approaches to exposure mapping are still at a basic stage, partly because the methodology does not only require quantitative approaches but must also integrate qualitative factors (Birkmann \& Fernando, 2008). Among the suggestions proposed by the Institute for the Environment and Human Security (United Nations University, report no. 5/2006), Birkmann and Wisner (2006) highlighted the importance of developing methods to address the particular circumstances of each case study; the need to join qualitative and quantitative data in the methodologies and the necessity of properly approaching the scale factor. In brief, specific methods must be designed according to the accessibility of data and the features of the study area so that the best solution can be applied and adapted to each working scale.

Along these lines, Camarasa et al. (2011) have devised a simple method to assess and map exposure based on land use, following the work carried out by Grünthal et al. (2006). The method uses the assumption that when faced with a similar hazard level, losses will be greater in areas of intense human occupation (residential use) with high economic value. Thus, the authors estimated exposure by the price of land, and the density of human occupation in the area. In addition, as this intensity varies at different times of the day (population density is lower or higher in an area according to whether we are referring to working hours, a holiday or night time) three exposure maps were drawn up to cater for three scenarios: working hours, holidays and nights. The three maps are interesting because they allow for the design of spatially accurate strategies for emergency management, based on time frames. During the day, the highest levels of exposure are located at work, school and business centers, while at night the most exposed zones are residential areas. During holidays, places of entertainment may be the worst affected. However, since this is a methodological paper, and in order to avoid repetition, only one of the maps proposed by Camarasa et al. (2011), the working hours map, has been chosen to carry out the methodological proposal, as it shows a greater spatial differentiation of exposure. The method used to draw up this map is briefly explained below, although the original work published by Camarasa et al. (2011) provides more detailed information.

\subsubsection{Cartography of economic land value}

Estimating the economic land value from land use is a commonly used approach to map potential spatial losses produced by natural disasters (Blong, 2003; Ferrier \& Haque, 2003; Grünthal et al., 2006). The methods vary from rough indices (Ferrier \& Haque, 2003) to refined evaluations based on complex calculations (Collins, Grineski, \& Romo, 2009; Tran, O’Neill, \& Smith, 2010; Vinet, 2008; Wood, 2009). Selecting the best option depends largely on the availability of information and on the working scale used. Mediterranean environments have historically shown great changes in land use (easily traceable by remote sensing over the last few decades), however there is a lack of spatially distributed socioeconomic information that limits the kind of analysis that can be conducted (Maantay \& Maroko, 2009; Pelorosso, Leone, \& Boccia, 2009; Serra, Pons, \& Saurí, 2008).

The economic valuation map was designed by assigning prices to the different types of use of each category: residential, industrial, tertiary, farming and natural/uncultivated land. Each category of use was assigned an economic value of reference based on market prices, estimated from the Cadastre (although we are aware that this is not a real market value, it serves as a benchmark to compare). It is assumed that the losses that would occur if the territory were affected by flooding would center on the land use price.

Prices were assigned according to a previous study of the spatial distribution of land values defined on use categories. For farming uses, five subtypes were contemplated: (1) citrus, (2) irrigated arable, (3) non-irrigated arable, (4) forestry and (5) pasture/fallow. By comparing prices per hectare for each subtype in the different municipalities, an average price for each agricultural type of land was assigned.

In terms of urban uses (residential, industrial, services), a representative price for each type of land was not found. However, through an analysis of specialized literature on the issue (Cervelló, 2008; Mills, 1967; Muth, 1975), the authors found a strong inverse correlation between land prices and distance to the Central Business District (CBD). Therefore, the prices for urban uses were estimated by a model based on the inverse ratio of the distance to the city of Valencia's CBD.

Finally, public utilities were not evaluated in terms of economic value because the value of these services is strategic but not in terms of the area they occupy.

\subsubsection{Cartography of human exposure}

Exposure is determined by the population density of an area: places with greater population density are more vulnerable when flooded. As mentioned above, the original work on which part of this article is based (Camarasa et al., 2011) features three exposure maps for working hours, nights and holidays. As this paper does not aim to study the time differences of exposure, but rather addresses spatial distribution, we shall only analyze the exposure map for working hours.

The human exposure map taken from the cited article was created by assigning levels from 0 (minimum value of exposure) to 8 (maximum value). The maximum assessment (8) was assigned 
Table 1

Hazard level assessment based on the hydrogeomorphological interpretation.

\begin{tabular}{|c|c|c|}
\hline $\begin{array}{l}\text { LANDFORM } \\
\text { AND } \\
\text { PROCESS }\end{array}$ & DESCRIPTION & $\begin{array}{l}\text { HAZARD } \\
\text { RANKING }\end{array}$ \\
\hline Channel & $\begin{array}{l}\text { The channels are the main waterways, although the Mediterranean } \\
\text { ephemeral streams are dry most of the year. During flooding events, } \\
\text { speed and water depth are high, as well as the number and size of } \\
\text { transported sediment. }\end{array}$ & 1 \\
\hline $\begin{array}{l}\text { Break-prone } \\
\text { points in } \\
\text { channel }\end{array}$ & $\begin{array}{l}\text { These take place in areas where the channels have sharp bends, near } \\
90^{\circ} \text {. Some of the factors that help the break of banks are: low slope, } \\
\text { lack of natural levees, low trenching, presence of obstacles in the } \\
\text { channel and formation of flow pressure eddings. Flow can reach } \\
\text { high speed and transport large size sediments. }\end{array}$ & 1 \\
\hline $\begin{array}{l}\text { Deficient } \\
\text { drainage } \\
\text { areas }\end{array}$ & $\begin{array}{l}\text { Areas with a deficient drainage because the channel disappears } \\
\text { when trenching decreases (in alluvial fans or floodplains) or when } \\
\text { channel reaches a semi-endorheic region. There, water can stagnate } \\
\text { for a variable period of time. }\end{array}$ & 2 \\
\hline $\begin{array}{l}\text { Crevasses } \\
\text { and splays }\end{array}$ & $\begin{array}{l}\text { These take place in natural levees or man-made dikes built using } \\
\text { clay materials. When the banks are full, water erodes the levee and } \\
\text { spills into the floodplain, transporting a large amount of sediment. }\end{array}$ & 2 \\
\hline Swamps & $\begin{array}{l}\text { Low lands that are frequently flooded. In general, swamps collect } \\
\text { water from different overflowed streams. Flows gently extend and } \\
\text { lose speed as they move away from the channels. Floods are } \\
\text { prolonged because the water cannot drain easily into the sea. }\end{array}$ & 3 \\
\hline $\begin{array}{l}\text { Waterways } \\
\text { and } \\
\text { paleochannels }\end{array}$ & $\begin{array}{l}\text { Waterways and paleochannels are ancient channels (normally not } \\
\text { functional nowadays) that act as secondary drainage in a flood } \\
\text { event, collecting the floodwater which comes from the main channel } \\
\text { or which comes down from the slopes. Generally, in floodplain of } \\
\text { convex geometry, they have difficulty draining as the water cannot } \\
\text { return to the main channel because of the levees on its banks. }\end{array}$ & 4 \\
\hline Floodplain & $\begin{array}{l}\text { The water that overflows out of the channel extends smoothly across } \\
\text { this almost flat surface. Relatively low depth and speed. }\end{array}$ & 5 \\
\hline Alluvial fans & $\begin{array}{l}\text { The channel can disappear at the intersection with the alluvial fan } \\
\text { surface (because the slope and trenching decreasing), and the flow } \\
\text { extends to cover the distal part of the fan; low speed and depth. }\end{array}$ & 6 \\
\hline $\begin{array}{l}\text { Natural } \\
\text { levées and } \\
\text { dikes }\end{array}$ & $\begin{array}{l}\text { Levées and dikes are elevated landforms, so they only become } \\
\text { flooded in high episodes, when bankfull stage is exceeded; low } \\
\text { depth and speed water. }\end{array}$ & 6 \\
\hline Glacis & $\begin{array}{l}\text { An erosional or depositional pediment, rarely flooded, except during } \\
\text { exceptional floods. In this case, the water level is very low. }\end{array}$ & 7 \\
\hline $\begin{array}{l}\text { Sheet flow } \\
\text { sediments }\end{array}$ & $\begin{array}{l}\text { Alluvial sediments covering distal fan areas, pediments or low part } \\
\text { of slopes. Very low or no flood hazard. }\end{array}$ & 8 \\
\hline $\begin{array}{l}\text { Longshore } \\
\text { bar }\end{array}$ & $\begin{array}{l}\text { Sandy bar closing continental wetlands, off the shoreline of the sea. } \\
\text { Very low or no flood hazard (even though it can be eroded in a more } \\
\text { detailed scale). }\end{array}$ & 8 \\
\hline Mountains & No flood hazard. & 8 \\
\hline
\end{tabular}

to schools and hospitals, while the lowest level (0) corresponds to rural uses (agriculture, forestry, pasture/fallow) and to natural categories of use (fluvial channels, lagoons, etc.). Urban uses show intermediate exposure levels (according to their occupation density).

\subsubsection{Cartography of global exposure}

The mapping of global exposure has been qualitatively assessed by combining the maps for economic land value and human exposure (Camarasa et al., 2011). The global exposure assessment was carried out by a panel of experts in land planning and earth sciences (risk and emergency managers, land planning experts, social and human geographers, physical geographers and hydrologists).

The method used was a cross-tabulation of the original maps (economic value of land and human exposure), and the subsequent assignment of a level of exposure (ranking from 1 to 10) for each category intersection. The assessment of the exposure value was conducted by a panel of experts based on their knowledge of the territory and by using the pair-comparison technique method. Firstly, qualitative and quantitative categories of the original maps were ordered (ordinal scale), based on their susceptibility to flood exposure. Secondly, a cross-tabulation between the ordered categories of each map was developed. The expert panel then proceeded to analyze the intersection matrix by assigning an exposure value to each intersection, according to the interaction between the pairs of matching categories. Thus an ordinal exposure scale was obtained, which served to create the global exposure map.

This type of approach (basically an adapted Delphi method) is widely used to qualitatively assess interaction between variables of a very different nature (Ferrier \& Haque, 2003; Grünthal et al., 
2006) when linear or mathematical analyses are not suitable, as it combines the information available with the expertise of specialists (in this case, in territorial issues and flood risk).

\subsubsection{Estimating and mapping risk}

Risk maps were obtained by integrating the results obtained from hazard and global exposure mapping (Table 2). A total of ten risk levels were established on a qualitative scale in which 1 was the highest and 10 was the lowest. The levels were assigned by the same panel of experts. As above, linear functions were not followed. Instead, each intersection between hazard categories and global exposure was qualitatively assessed.

The combinations that contained the highest hazard level (1 channels and break-prone points) were assessed as a grade 1 risk, regardless of their global exposure level because they are highly hazardous areas which must be analyzed in detail and in any case, are not suitable for urban use.

In the next intersections (hazard levels between 2 and 6), the risk increases as global exposure rises. Lower hazard levels (6 and 7) imply a relatively low risk as they involve geomorphological elements (dikes and glacis) which have a comparatively low hazard risk. The risk only increases in cases in which global exposure is very high (levels 8, 9 and 10).

Finally, the areas affected by combinations that include low or no hazard (level 8) are considered to be safe from flooding, because, although they have high global exposure, they are free from threats. There is only one exception, the intersection between the sheet flow and level 10 global exposure, represented by extremely vulnerable public utilities, which, even if only slightly flooded, would involve huge damage to the surrounding population.

Special mention must be made of major roads and railways at this point. Although they cannot be assessed at this scale, they run perpendicular to the direction of major waterways (whether flooded or not). We are well aware that a general article such as this one cannot aim to assess the risk of these infrastructures as this would requires a specific analysis of their particular drainage systems, built according to specific legal regulations, which cannot be seen on this general scale. However, we must point to the need for more detailed case study analysis in this area.

\section{Results}

The main results of hazard, global exposure and risk mapping in the Carraixet and Poyo floodplains are detailed below.

\subsection{Flood hazard map}

Fig. 3 shows the hazard map for the Carraixet and Poyo floodplains respectively. In the Carraixet floodplain, the greatest hazard (level 1) is associated with break-prone points in the channel's banks (where the main channel intersects with the CV-315 road) as well as with the actual channel itself. The breaking of both banks at this spot creates two waterways (which run parallel to the channel) which flow down to the sea through paleochannels in the Pleistocene alluvial fan. The right-bank paleochannel is the most hazardous as it can transport overflows from the Carraixet, converging with the Barranco del Palmaret ravine and other fluviokarstic paleochannels which partly run off a tectonic limestone platform on the right bank (Camarasa, 1995). When waters rise, this huge streambed on the right bank becomes active down to the sea, thus creating an especially floodable area in the Marjal de Montcada marsh (level 2) and in the coastal wetland (level 3). The Montcada marsh is an influx point for water which has either poured through the upstream right-bank break point, or which has overflowed from the main channel. This flow cannot return to the main channel downstream because of the convex topography of the floodplain (a natural levee on the channel's right bank prevents flow from reaching the main channel). Thus, overflowing water must reach the sea, creating a parallel course (yazoo) that floods the land it flows through (Camarasa, 1995).

Other minor streambeds and paleochannels have a medium hazard level (5). In its final stretch, the channel is flanked by a dike, which is raised up above the plain and is less hazardous (6). Finally, the areas which are practically safe (level 8 ) are the mountains, the sheet-flow and the longshore bar.

In the Rambla de Poyo, in addition to the channel itself, the most hazardous area (level 1) is downstream of the intersection with the V-31 road. According to Ruíz and Carmona (2004), dikes which border the channel are frequently breached causing crevasses and splays which transfer water and sediment to the floodplain. This mapping includes the weak points which were breached in four places in the great flood episode of October 2000 and through which stream flow eroded the soil in the adjoining cultivated fields (Ruíz \& Carmona, 2004). In fact, two months after the floods the overflow sediments could still be seen in IKONOS images (López-García, Carmona, Ruíz, \& Camarasa, 2006).

Another hazardous area (level 2) is the eastern section of the area under study, which is mainly occupied by the Albufera lagoon. This area is often waterlogged due to increases in the water table and a build-up of overflow water because it is wetland.

Finally, there is the area where the towns of Catarroja and Massanassa stand in relation to the Barranco de Torrent's alluvial fan (level 6). The dikes, glacis and longshore bar are the least hazardous areas (levels 7 and 8).

\subsection{Global exposure map}

The global exposure maps are shown in Fig. 4. Generally speaking, in the Carraixet plain, the area of greatest global exposure is located to the south of its final section, in the districts to the north of the city of Valencia and the towns of Tavernes Blanques, Alboraia and La Patacona. These are the areas in which land prices are highest and there is greater building density which results in high exposure. The towns clustered around the former Valencia-Barcelona road (CV-300), the conurbation of Burjassot-Paterna and the towns of Montcada, Vinalesa, Rocafort and Godella are also more exposed.

Generally, this is a farming floodplain which does not have large industrial concentrations and where the majority of its inhabitants are employed in the city of Valencia (excluded from the study zone). Nevertheless, it shows a significant residential role as it acts as a bedroom community for Valencia and as an area for second homes.

The Poyo plain partly reproduces the Carraixet's characteristics in that the highest levels of global exposure are concentrated around Valencia. There are three particularly problematic areas: (1) the northeast sector of the plain which is a heavily built up urban and industrial area (Torrent, Aldaia and Alaquàs); (2) the towns of Paiporta and Picanya and their respective industrial estates; and (3) the continuum of towns and industrial estates clustered around the former Camino Real de Madrid road.

\subsection{Flood risk map}

Fig. 5 shows the flood risk in the Carraixet and Poyo floodplains. Broadly speaking, there are two large areas in the Carraixet plain to the north and south of the main channel where the risk is highest. The southern section is the most important as it combines the areas with the greatest hazard level with the areas which suffer the greatest global exposure as a result of intense residential and industrial occupation. The other smaller, less important section is located towards the north of the Carraixet plain, and is linked to wetland areas. 
Table 2

Risk level assessment based on hazard and global exposure levels (the risk value 1 represents the highest risk and the lowest value 10 ).

\begin{tabular}{|c|c|c|c|c|c|c|c|c|c|c|c|c|}
\hline \multirow[b]{2}{*}{ Landform / Process } & \multirow[b]{2}{*}{$\begin{array}{l}\text { HAZARD } \\
\text { RANKING }\end{array}$} & \multicolumn{11}{|c|}{ GLOBAL EXPOSURE LEVEL } \\
\hline & & $\mathbf{0}$ & 1 & 2 & 3 & 4 & 5 & 6 & 7 & 8 & 9 & 10 \\
\hline Channel & 1 & 1 & 1 & 1 & 1 & 1 & - & 1 & - & - & - & - \\
\hline Break-prone points in channel & 11 & 1 & - & 1 & 1 & 1 & - & - & - & - & - & - \\
\hline Deficient drainage areas & 2 & - & 4 & 4 & 3 & 2 & 2 & 2 & - & 1 & 1 & 1 \\
\hline Crevasses and splays & 2 & - & 4 & 4 & 3 & 2 & 2 & 2 & - & - & - & 1 \\
\hline Swamps & 3 & - & 4 & 4 & 3 & 3 & 3 & 2 & 2 & 1 & 1 & 1 \\
\hline Waterways and paleochannels & 4 & 4 & 4 & 4 & 3 & 3 & 3 & 2 & 2 & 1 & 1 & 1 \\
\hline Floodplain & 5 & 6 & 6 & 5 & 4 & 4 & 3 & 3 & 3 & 2 & 2 & 2 \\
\hline Alluvial fans & 6 & - & 6 & 5 & 4 & 4 & 3 & 3 & 3 & 2 & 2 & 2 \\
\hline Natural levées and dikes & 6 & 8 & 8 & 8 & 8 & 8 & 8 & 8 & - & 6 & 6 & 6 \\
\hline Glacis & 7 & 9 & 9 & 9 & 8 & 8 & 8 & 8 & 8 & 8 & 7 & 7 \\
\hline Sheet flow sediments & 8 & 10 & 10 & 10 & 10 & 10 & 10 & 10 & 10 & 10 & 10 & 7 \\
\hline Longshore bar & 8 & 10 & 10 & 10 & 10 & 10 & 10 & 10 & 10 & 10 & 10 & 10 \\
\hline Mountains & 8 & 10 & 10 & 10 & 10 & 10 & 10 & 10 & 10 & 10 & 10 & 10 \\
\hline
\end{tabular}

The highest risk areas in the Poyo floodplain are the residential and industrial towns of Catarroja, Massanassa, Alfafar and Benetússer, which are located on the Rambla del Poyo alluvial fan. This is a relatively compact area in line with the former Camino Real de Madrid road with highly distinct uses marked by the Valencia-Albacete-Madrid railway line.

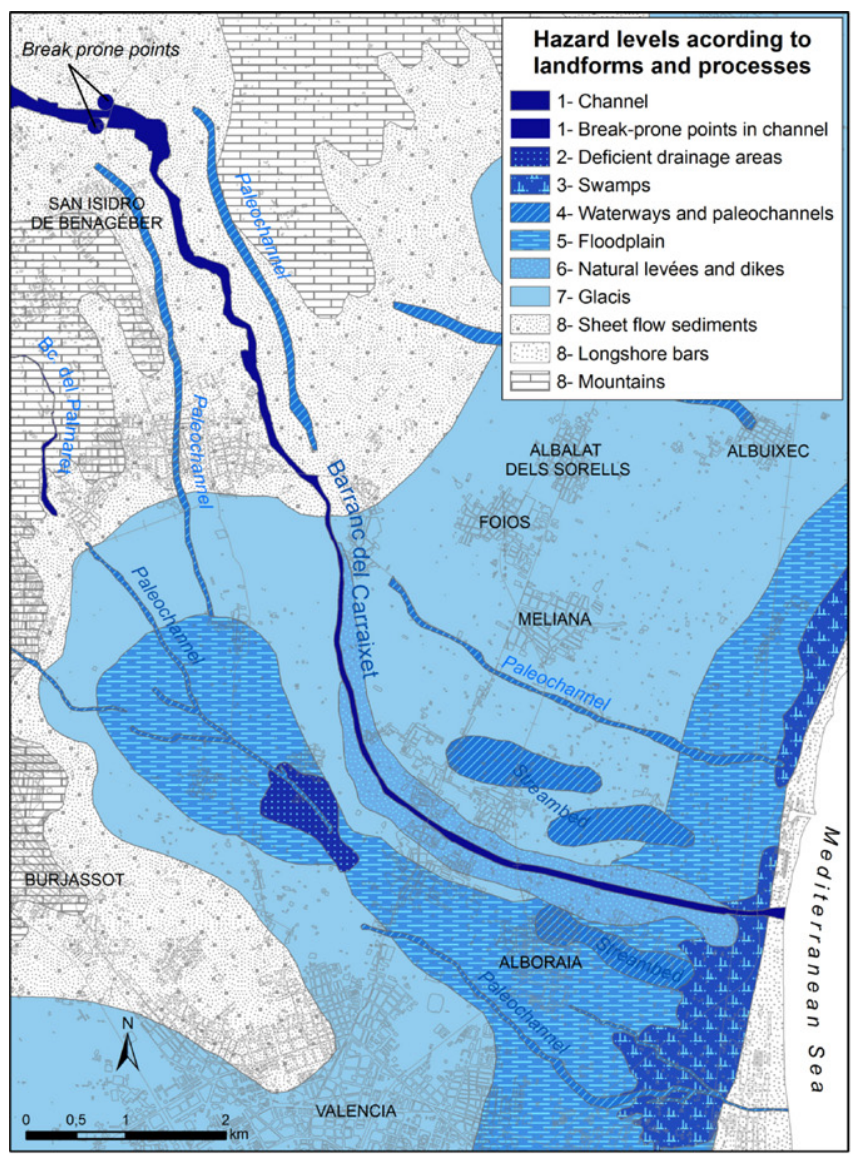

Carraixet floodplain
Risk mapping shows a different pattern in the Carraixet and Poyo floodplains. This stems from how global exposure evolved over the last half of the 20th century in these areas. Even though both floodplains are included in the peri-urban area of Valencia and have been impacted by urban expansion over the last 50 years, land occupation has been different in that in the Poyo floodplain has been highly influenced by the diversion of the River Turia as a consequence of

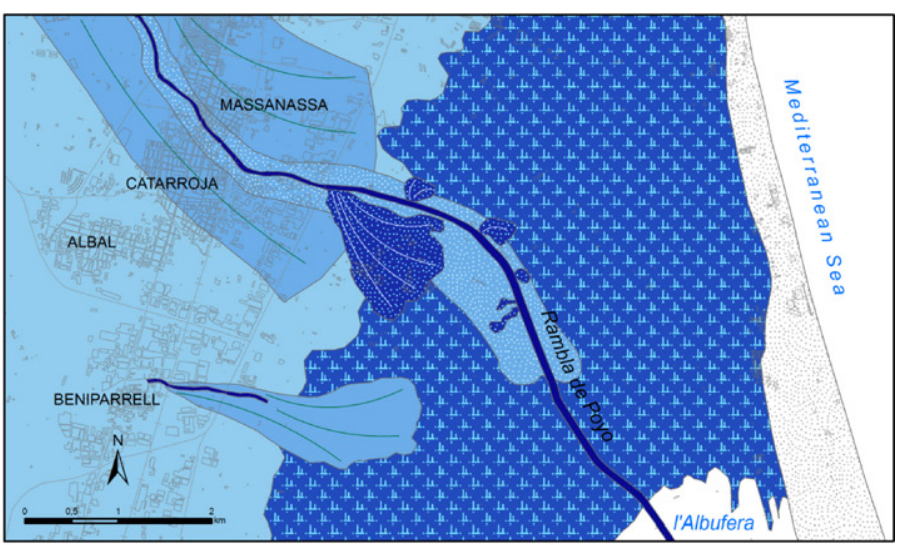

Hazard levels acording to landforms and processes 1-Channel 6-Alluvial fans

Poyo floodplain

2- Crevasses and splays

개레 3- Swamps

7- Glacis

8- Longshore bars

6- Natural levées and dikes

Fig. 3. Hazard maps of Carraixet and Poyo floodplains. 


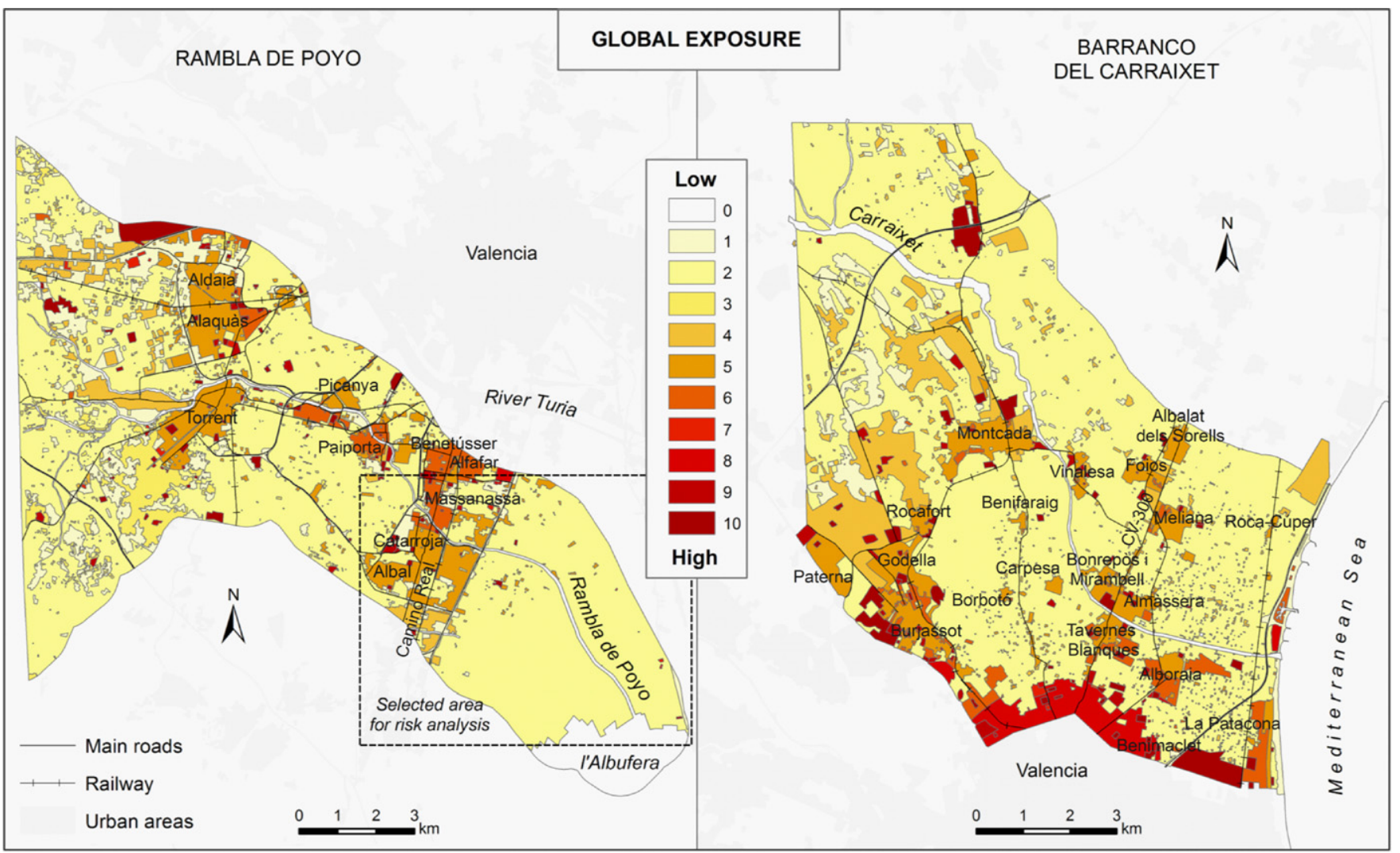

Fig. 4. Global exposure maps of Carraixet and Poyo floodplains.
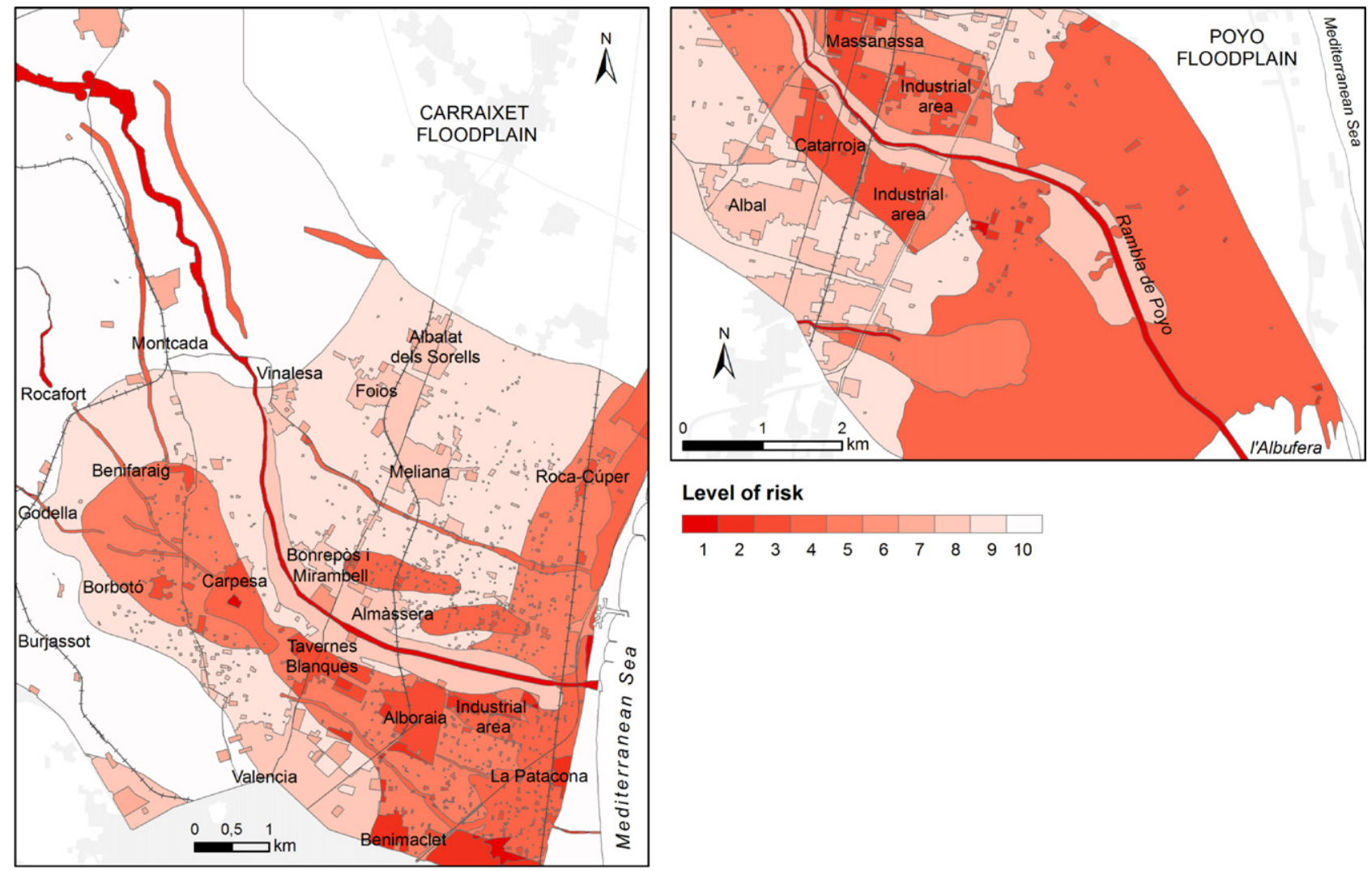

\section{Level of risk}

$\begin{array}{llllllllll}1 & 2 & 3 & 4 & 5 & 6 & 7 & 8 & 9 & 10\end{array}$

Fig. 5. Risk maps of Carraixet and Poyo floodplains. 

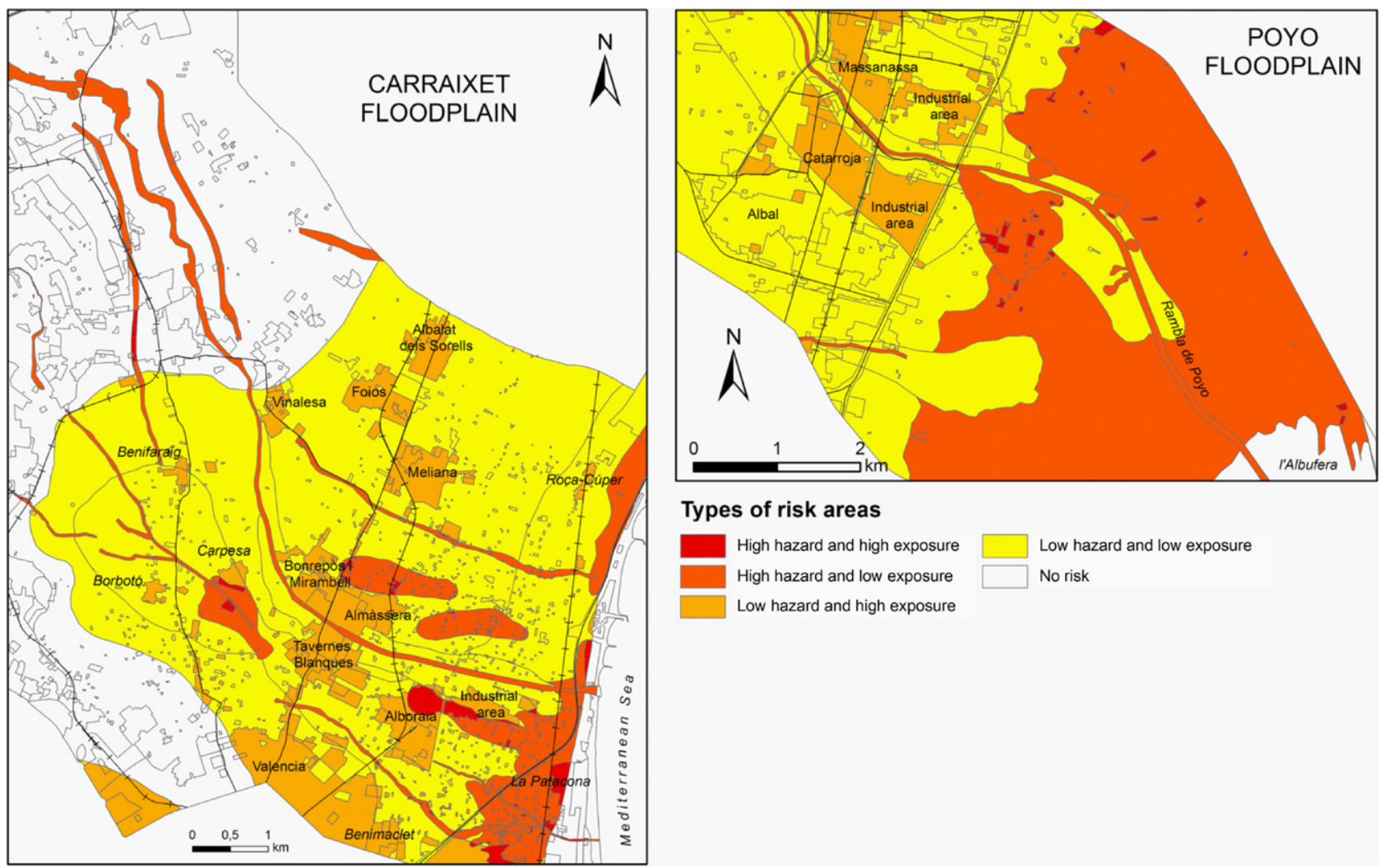

Types of risk areas

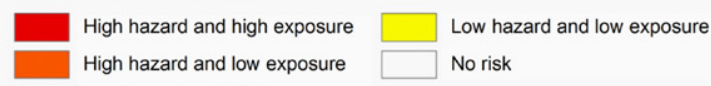

Low hazard and high exposure

Fig. 6. Types of risk area in Carraixet and Poyo floodplains, depending on its hazard and exposure components.

the floods of 1957 . This diversion, which crosses the Poyo plain, played a part in the rapid dismantling of the farming systems in l'Horta Sud and in the concentration of its industrial, service and road and rail infrastructure. The Carraixet floodplain, nevertheless, has mainly retained its farming organization and the change in use has moved towards the construction of urban dwellings. The different economic structure of both areas has thus shaped different global exposure patterns, which have in turn conditioned different risk models.

\subsection{Types of risk area}

Risk analysis based on hazard and global exposure allows risk area types to be identified according to the intensity and quality of their components. This synthesis mapping is very useful for land use planning as it enables a swift diagnosis of the nature of the risk (natural factors or human factors) and it helps decision-making in risk management strategies. The maps in Fig. 6 provide an example of this cartography and show four basic types of risk area:

(a) High hazard and high global exposure: this is the situation which involves the greatest risk. It is a result of the combination of high hazard levels (streambeds, marshes, deficient drainage areas, breakages, crevasses and splays, ...) with the most exposed elements, such as hospitals, educational centers and public utilities.

(b) High hazard and low global exposure: this refers to areas which have major hazards because they are in highly floodable areas. However, their global exposure is low because the land is mainly rural (the most compatible with flooding) with scarce human exposure.

(c) Low hazard and high global exposure: this category is mainly related to urban uses as it refers to highly exposed areas of high economic value and high human exposure, which are established on low hazard areas, such as glacis, natural levees and alluvial fans.

(d) Low hazard and low global exposure: in this case, the risk is low or non-existent. This is the case of rural areas, especially those with low economic value, established in areas where the hazard is very low (for example, rain-fed crop land on mountain slopes).

A comparative analysis of both zones strengthens the idea that they follow different patterns. In general, the Poyo plain has a simpler layout, with a large surface area classed as high hazard and low global exposure, mainly centered on the wetland that surrounds the Albufera lagoon. This wetland is a flood-prone area, which is basically farmland that should not be used for urban use. The Carraixet plain is more complex as the hazards come from different waterways and surface runoff paleoforms. The urban growth which is taking place in this area is significant as predominantly rural land use is giving way to increasing residential occupation. The high hazard low global exposure category is particularly interesting as it may contribute to streamlining future land occupation and the location of public utilities.

Finally, we must again mention the major road and rail networks which run perpendicular to the general runoff direction and constitute a major hazard factor. However, as we mentioned above, it is not part of this study to tackle the impact of these infrastructures given its general scale.

\section{Discussion and conclusions}

Flood risk in Mediterranean ephemeral streams requires a special approach as these streams are highly torrential systems that can be very destructive. They remain dry most of the year, but when they flow, they become highly devastating. Large flash floods are generated and the population has little time to react. They create 
changeable floodable zones in areas of large-scale human occupation. This fact, together with a lack of hydrological data, advises the use of simple hazard assessment models that can be transferred to other contexts and adapted to the powerful dynamics of these basins.

This paper puts forward a method to map flood risk in ephemeral streams based on estimating hazard and global exposure which has been applied to the Barranco del Carraixet and Rambla de Poyo floodplains. Natural hazards were assessed using hydrogeomorphological methods and global exposure was assessed as the combination of the economic value and human occupation of land. The procedure was based on the progressive combination of maps, using qualitative cross-tabulation techniques. Each intersection matrix was analyzed by a panel of experts who assigned ordinal scales of hazard, exposure or risk (depending on the resulting map) based on their individual expertise and knowledge of the territory.

The hydrogeomorphological method has proved to be extremely efficient in interpreting flood processes in this type of intermittentflowing, highly torrential basin in which standard hydrolological and hydraulic models prove inadequate (Ballais et al., 2005; Diakakis, 2011; Díez-Herrero et al., 2008; Guzzetti et al., 2005; Lastra et al., 2008; Ortega \& Garzón, 2009). This method enables analysis with scarce hydrological data and is highly flexible as any change in the floodable area's morphology (whether natural or human-induced) can be included in a hydrogeomorphological map and be easily assessed in hazard terms. In this sense, Mediterranean environments are highly dynamic from a hydrogeomorphological point of view. A single high-energy event can significantly alter the geomorphology of the floodplains by creating new erosive (crevasses, bank-break, entrenchment, etc.), or sedimentary forms (splays, alluvial fans, debris flow, etc.). In these cases, the hazard map can be updated relatively quickly by mapping the new forms and assigning them with a flood hazard value. Thus, adapting hazard maps to new hydrogeomorphological conditions is fast and economical.

Global exposure assessment and mapping is based on a previous article by Camarasa et al. (2011) which uses a simple method based on land use and its cadastral value (readily available public data). This method, like the hazard map, can be adapted to changes in land occupation as they take place by updating land use.

In general, it is a simple method which can easily be transferred to other areas. It combines both quantitative and qualitative approaches in such a way that the peculiarities of each case can be input using the assessments made by a panel of experts (both in hazard estimation based on hydrogeomorphology, and global exposure based on land use indicators). Thus, it is efficient, flexible and highly adaptable.

Beyond Mediterranean environments, the method may be particularly interesting for arid and semi-arid morphoclimatic environments, where most of the fluvial systems are ephemeral and torrential streams (with absence of base flow); storms are extremely intense and there is a considerable lack of quality hydrological data with which to analyze the processes and fit the standard hydrological models. In addition, the plains of these fluvial systems concentrate a large number of people because of their economic potential. A rough estimate of the land area included in arid, semiarid and Mediterranean environments takes in 30\% of Europe, $60 \%$ of Asia, $30 \%$ of South America, the southwest area of North America and most of the African and Australian continents.

Synthesis mapping enables different risk area types to be identified according to their hazard and global exposure components. It is a useful tool for spatial planning and decision-making because it enables a rapid interpretation of the nature of the risk. It also can facilitate the design of preliminary mitigation strategies to reduce flood risk, either by acting on the hazard (structural measures: channeling, dams, etc.) or on exposure (planning alternative land uses).

We are aware of the fact that the cartography presented in this article is only a risk diagnosis phase and that the study must be carried out on a more detailed town-planning scale. However, the method can feasibly be scaled up. It only requires identifying and assessing the elements which make up hazard and global exposure for each scale. We therefore believe that the simplicity, versatility and flexibility of the method and the small amount of data required to implement it constitute a useful tool to study flood risk in Mediterranean and semi-arid environments.

\section{Acknowledgements}

This work was carried out thanks to funding from the Spanish Ministry of Science and Innovation, project CGL2007-65368, co-financed by FEDER funds. J. Soriano wishes to acknowledge the grant received from the Programa Nacional de Formación de Profesorado Universitario (FPU) conceded by the Spanish Ministry of Science.

\section{References}

Adger, W. N. (2006). Vulnerability. Global Environmental Change, 16, 268-281.

Aven, T. \& Kristensen, V. (2005). Perspectives on risk: Review and discussion of the basis for establishing a unified and holistic approach. Reliability Engineering and System Safety, 90(1), 1-14.

Baker, V. R., Kochel, R. C. \& Patton, P. C. (1988). Flood geomorphology. Toronto: Wiley Interscience.

Ballais, J. L., Garry, G. \& Masson, M. (2005). Contribution of hydrogeomorphological method to flood hazard assessment: The case of French Mediterranean region. Comptes Rendus Geoscience, 337(13), 1120-1130.

Benito, G., Lang, M., Barriendos, M., Llasat, C., Francés, F., Ouarda, T., et al. (2004). Use of systematic, paleoflood and historical data for the improvement of flood risk estimation. Review of Scientific Methods. Natural Hazards, 31, 623-643.

Birkmann, J. (2007). Risk and vulnerability indicators at different scales: Applicability, usefulness and policy implications. Environmental Hazards, 7, 20-31.

Birkmann, J. \& Fernando, N.(2008). Measuring revealed and emergent vulnerabilities of coastal communities to tsunami in Sri Lanka. Disasters, 32(1), 82-105.

Birkmann, J. \& Wisner, B. (2006). Measuring the un-measurable. The challenge of vulnerability. Source no. 5/2006. Bonn: United Nations UniversityInstitute for Environment and Human Security. Available from. http://www.ehs.unu.edu/file/get/3962

Blong, R. (2003). A new damage index. Natural Hazards, 30(1), 1-23.

Bohle, H. G. (2001). Vulnerability and criticality: Perspectives from Social Geography. Update IHDP, Newsletter of the International Human Dimensions Programme on Global Environmental Change 2/2001. Available from http://www.ihdp.unibonn.de/html/publications/update/update01_02/IHDPUpdate01_02 bohle.html

Brilly, M. \& Polic, M. (2005). Public perception of flood risks, flood forecasting and mitigation. Natural Hazards and Earth System Science, 5(3), 345-355.

Braken, L. J., Cox, N. J. \& Shannon, J. (2008). The relationship between rainfall inputs and flood generation in south-east Spain. Hydrological Processes, 22(5), 683-696.

Bull, L. J., Kirkby, M. J., Shannon, J. \& Hooke, J. M. (2000). The impact of rainstorms on floods in ephemeral channels in southeast Spain. Catena, 38, 191-209.

Camarasa, A. M. (1995). Génesis de crecidas en pequeñas cuencas semiáridas. Barranco de Carraixet y Rambla del Poyo (Flood generation in small semi-arid catchments: Carraixet and Poyo Basins). In Ministerio de Obras Públicas, Transportes y Medio Ambiente, Confederación Hidrográfica del Júcar (in Spanish).

Camarasa, A. M. (2006). Inundaciones en España. Tipología. La importancia de las avenidas súbitas (Floods in Spain. Typology. The importance of flash-floods). Riesgos Naturales y Desarrollo Sostenible. Impacto, Predicción y Mitigación, I.G.M.E., Serie Medio Ambiente. Riesgos Geológicos, 10, 167-178 (in Spanish).

Camarasa, A. M., López-García, M. J. \& Soriano, J. (2011). Mapping temporallyvariable exposure to flooding in small Mediterranean basins using land-use indicators. Applied Geography, 31, 136-145.

Camarasa, A. M. \& Segura, F. (2001). Flood events in Mediterranean ephemeral streams (ramblas) in Valencia region, Spain. Catena, 45, 229-249.

Camarasa, A. M., Soriano, J. \& López-García, M. J. (2010). The effect of observation timescales on the characterisation of extreme Mediterranean precipitation. Advances in Geosciences, 26, 61-64.

Camarasa, A. M. \& Tilford, K. (2002). Rainfall-runoff modelling of ephemeral streams in the Valencia Region Eastern Spain. Hydrological Processes, 16, 3329-3344.

Cervelló, R. E. (2008). Evolución del mercado inmobiliario en centros urbanos. Efectos de la política de intervención pública (Housing market developments in urban centers. Effects of public policy intervention). Doctoral thesis. Departamento de Economía y ciencias sociales. Universidad Politécnica de Valencia. Available from http://dspace.upv.es/xmlui/bitstream/handle/10251/3342/tesisUPV2904.pdf? sequence $=11$ (in Spanish) 
Chave, S. (2002). Pertinence de la cartographie hydrogéomorphologique dans l'approche des inondations rares à exceptionnelles: Exemples de sept bassins fluviaux dans les Corbières et le Minervois (Convenience of hydrogeomorphological mapping in the study of exceptional floods: Cases of study of seven rive basins, in the regions of Cobières and Minervois). Géomorphologie, 4, 297-306 (in French)

Collins, T. W., Grineski, S. E. \& Romo, M. L. (2009). Vulnerability to environmental hazards in the Ciudad Juárez Mexico-El Paso USA metropolis: A model for spatial risk assessment in transnational context. Applied Geography, 29, 448-461.

Conesa-García, C. (1995). Torrential flow frequency and morphological adjustments of ephemeral channels in South East Spain. In E. J. Hickin (Ed.), River morphology (pp. 169-192). Chichester: Wiley.

Cutter, S. L. \& Finch, C. (2007). Temporal and spatial changes in social vulnerability to natural hazard. In Turner, B.L., II, Clark University, Worcester, MA. PNAS, 105(7) 2301-2306. Available from. www.pnas.org/cgi/doi/10.1073/pnas.0710375105

Dake, K. (1991). Orienting dispositions in the perception of risk. An analysis of contemporary worldviews and cultural biases. Journal of Cross-cultural Psychology 22(1), 61-82.

Diakakis, M. (2011). A method for flood hazard mapping based on basin morphometry: Application in two catchments in Greece. Natural Hazards, 56, 803-814.

Dick, G., Anderson, R. \& Sampson, D. (1997). Controls on flash flood magnitude and hydrograph shape, Upper Blue Hills badlands, Utah. Geology, 25(1), 45-48.

Díez-Herrero, A., Ballesteros, J. A., Llorente, M., Bodoque, J. M., Stoffel, M., Eguíbar M. A., et al. (2008). Towards a classification of dendrogeomorphological evidences and their utility in flood hazard analysis. Geophysical Research Abstract, $10,07837$.

Ferrier, N. \& Haque, C. E. (2003). Hazards risk assessment methodology for emergency managers: A standardized framework for application. Natural Hazards, 28(2-3), 271-290

Graf, W. L. (1988). Fluvial processes in dryland rivers. Berlin: Springer-Verlag.

Greenbaum, N., Margalit, A., Shick, A. P., Sharon, D. \& Baker, V. R. (1998). A high magnitude storm and flood in a hyperarid catchment, Nahal Zin, Neveg Desert, Israel. Hydrological Processes, 12, 1-3.

Grünthal, G., Thieken, A. H., Schwarz, J., Radtke, K. S., Smolka, A. \& Merz, B. (2006) Comparative risk assessment for the city of Cologne, Germany -Storms, floods, earthquakes. Natural Hazards, 38(1-2), 21-44.

Guzzetti, F. \& Tonelli, G. (2004). Information system on hydrological and geomorphological catastrophes in Italy SICI: A tool for managing landslide and flood hazards. Natural Hazards and Earth System Science, 4(2), 213-232.

Guzzetti, F., Stark, C. P. \& Salvati, P. (2005). Evaluation of flood and landslide risk to the population of Italy. Environmental Management, 36(1), 15-36.

Hooke, J. M. (2006). Human impacts on fluvial systems in the Mediterranean region. Geomorphology, 79, 311-335.

Hooke, J. M. \& Mant, J. M. (2000). Geomorphological impacts of flood event on ephemeral channels in SE Spain. Geomorphology, 34, 163-180.

Insurance Compensation Consortium, 2008. Available from http://www.consorseguros.es/c/document_library/get_file?uuid=d9737999cbc0-4e79-8a9a-98100b433a3f\&groupId=10124

Jin, H.-S. \& Ward, G. M. (2005). Hydraulic characteristics of a small Coastal Plain stream of the southeastern United States: Effects of hydrology and season. Hydrological Processes, 19(20), 4147-4160.

Lana, X., Martínez, M. D., Serra, C. \& Burgueño, A. (2004). Spatial and temporal variability of the daily rainfall regime in Catalonia Northeastern Spain, 1950-2000. International Journal of Climatology, 24, 613-641.

Lasanta, T., García-Ruiz, J. M., Pérez-Rontomé, C. \& Sancho-Marcén, C. (2000). Runoff and sediment yield in a semi-arid environment: The effect of land management after farmland abandonment. Catena, 38, 265-278.

Lastra, J., Fernández, E., Díez-Herrero, A. \& Marquínez, J. (2008). Flood hazard delineation combining geomorphological and hydrological methods: An example in the Northern Iberian Peninsula. Natural Hazards, 45, 277-293.

Lewin, J. \& Manton, M. M. M. (1975). Welsh floodplain studies: The nature of floodplain geometry. Journal of Hydrology, 25(1-2), 37-50.

López-García, M. J., Carmona, P., Ruíz, J. M. \& Camarasa, A. M. (2006). El uso de imágenes Ikonos para la cartografía de riesgo de inundación en pequeñas cuencas semiáridas (The use of Ikonos images for mapping flood risk in small semiarid catchments). El acceso a la información espacial y las nuevas tecnologías geográficas. Granada, 949-957 (in Spanish).

Maantay, J. \& Maroko, A. (2009). Mapping urban risk: Flood hazard, race and environmental justice in New York. Applied Geography, 28, 111-124
Marco Segura, J. B. (2006). Los mapas de riesgo de crecidas en España Algunas reflexiones sobre 25 años cruciales (Flood risk maps in Spain. Some reflections after 25 critical years). In Díez Herrero, A., Lain Huerta, L., \& Llorente Isidro, M. (Eds.) Mapas de peligrosidad de avenidas e inundaciones. Métodos, experiencias y aplicación. Publicaciones del Instituto Geológico y Minero de España. Serie: Medio Ambiente. Riesgos Geológicos, 7, 11-15. Madrid (in Spanish).

Megnounif, A., Terfous, A., Ghenaim, A. \& Poulet, J.-B. (2007). Key processes influencing erosion and sediment transport in a semi-arid Mediterranean area: The Upper Tafna catchment, Algeria. Hydrological Sciences Journal, 52(6), 1271-1284.

Merrit, D. M. \& Wohl, E. E. (2003). Downstream hydraulic geometry and channel adjustment during a flood along an ephemeral, arid-region drainage. Geomorphology, 52, 165-180.

Mills, E. S. (1967). An aggregative model of resource allocation in a metropolitan area. American Economic Review, 85, 615-623.

Muth, R. F. (1975). Numerical solution of urban residential land use models. Journal of Urban Economics, 2, 307-332.

Ortega, J. A. \& Garzón, G. (2009). Geomorphological and sedimentological analysis of flash-flood deposits the case of the 1997 Rivillas flood (Spain). Geomorphology, 112,1-14.

Pelorosso, R., Leone, A. \& Boccia, L. (2009). Land cover and land use change in the Italian central Apennines: A comparison of assessment methods. Applied Geography, 29, 35-48.

Pilgrim, D. H., Chapman, T. G. \& Doran, D. G. (1988). Problems of rainfall-runoff modelling in arid and semiarid regions. Hydrological Sciences Journal, 33, 379-400.

Renard, K. G. \& Keppel, R. V. (1996). Hydrographs of ephemeral streams in the Southwest. Proceedings of the American Society of Civil Engineers, Journal of the Hydraulics Division, 92(2), 33-52.

Romero, R., Ramis, C. \& Guijarro, J. A. (1999). Daily rainfall pattern in the Spanish Mediterranean area: An objective classification. International Journal of Climatology, 19, 95-112.

Ruíz, J. M. \& Carmona, P. (2004). Flujos de inundación octubre del 2000 en el entorno de la Albufera de Valencia (Flood flows during October 2000 in the vicinity of the Albufera of Valencia). In G. Benito, \& A. Díez (Eds.), Riesgos naturales y antrópicos en Geomorfología (pp. 59-67). SEG y CSIC (in Spanish).

Salom, J. \& Albertos, J. M. (2006). Industria y ciudad. El Área Metropolitana de Valencia. Industria y ciudad en España: Nuevas realidades, nuevos retos (Industry and city. The metropolitan area of Valencia. Industry and cities in Spain new realities new challenges). In R. Méndez, \& H. Pascual (Eds.), Cizur Menor Navarra (pp. 273-306). Thomson-Civitas Estudios y monografías de economía (in Spanish).

Serra, P., Pons, X. \& Saurí, D. (2008). Land-cover and land-use change in a Mediterranean landscape: A spatial analysis of driving forces integrating biophysical and human factors. Applied Geography, 28, 189-209.

Servat, E., Najem, W., Leduc, C., \& Shakeel, A. (Eds.). (2003). Hydrology of Mediterranean and semiarid regions. IAHS Publ. 278. Wallingford, United Kingdom: IAHS Press.

Tooth, S. (2007). Arid geomorphology: Investigating past, present and future changes. Progress in Physical Geography, 31, 319-335.

Tran, L. T., O'Neill, R. V. \& Smith, E. R. (2010). Spatial pattern of environmental vulnerability in the Mid-Atlantic region, USA. Applied Geography, 30, 191-202.

UNDP, 2004. Reducing disaster risk. A challenge for development. Global Report. New York: United Nations Development Programme. Available from http://www.undp.org/cpr/disred/documents/publications/rdr/english/rdr_ english.pdf

Vinet, F. (2008). Geographical analysis of damage due to flash floods in southern France: The cases of 12-13 November 1999 and 8-9 September 2002. Applied Geography, 28, 323-336.

Wheater, H. S., Sorooshian, S. \& Sharma, K. D. (2006). Hydrological modelling for arid and semi-arid areas. Cambridge, UK: Cambridge University Press.

White, G. F. (1974). Natural hazards. Local, national, global. New York: Oxford University Press.

Wisner, B., Blaikie, P., Cannon, T. \& Davis, I. (2004). At risk: Natural hazards people's vulnerability and disaster. London: Routledge.

Wood, N. (2009). Tsunami exposure estimation with land-cover data: Oregon and the Cascadia subduction zone. Applied Geography, 29, 158-170.

Yair, A. \& Kossovsky, A. (2002). Climate and surface properties: Hydrological response of small arid and semiarid watersheds. Geomorphology, 42, 43-57.

Yair, A. \& Raz-Yassif, N. (2004). Hydrological processes in small arid catchment scale effects of rainfall and slope length. Geomorphology, 61, 155-169. 